\title{
Marine Stock Enhancement in India: Current Status and Future Prospects
}

\author{
Mohammad Serajuddin, Farah Bano, \\ Madhu Awasthi, Pragya Gupta and Graish Kumar \\ Additional information is available at the end of the chapter
}

http://dx.doi.org/10.5772/intechopen.75175

\begin{abstract}
India is a 12 mega-diversity nation known for its biodiversity richness. The geographic territory of India is an integral part of Central Indian Ocean Region consisting of three distinct marine ecosystem zones such as the Arabian Sea, Bay of Bengal and Indian Ocean. India is endowed with an exclusive economic zone of 2.02 million $\mathrm{km} 2$, coastline of over $8000 \mathrm{~km}$ and a variety of coastal ecosystems. The estimated number of marine fish species known from India constitutes 2443 species distributed in 230 families. According to the IUCN extant (2014), 50 species are threatened (6 of them critically endangered, 7 endangered and 37 vulnerable), while 45 are near-threatened. Marine fish diversity is in ever-increasing danger with depletion of resources. Overdependence on fish has led to overfishing resulting in the dwindling of diversity and abundance of stocks. Central Marine Fisheries Research Institute has initiated marine stock assessment practices in India and its present report in 2016 recorded a total of 709 species which is lower than 730 species recorded in 2015 in the landings showing an alarming situation on the exploited marine fishery resources of India. This situation demands restorative measures such as restocking, stock enhancement and sea ranching.
\end{abstract}

Keywords: depletion of fish resource, restorative measures, Central Indian Ocean

\section{Introduction}

Biodiversity is under threat worldwide, so a major issue of the twenty-first century [1]. Fish contribute more than one-half of the total number $(54,711)$ of vertebrate species recorded so far [2]. The descriptions of 33,059 species of fish are known from all over the world [3]. India is one among 12 mega-diversity countries because of its biodiversity richness. The Central 
Indian Ocean Region includes Indian Territory along with other countries such as Bangladesh, Indonesia, Maldives, Malaysia, Myanmar, Thailand and Sri Lanka.

The Central Indian Ocean Marine Region consists of the Arabian Sea, Bay of Bengal and a large area of the Indian Ocean south of India and Sri Lanka. Arabian Sea and Bay of Bengal bounding west and east coasts of the Indian peninsula merge with the Indian Ocean at the peninsula's southern most extremity. India having vast marine resources in the form of coastline (over $8000 \mathrm{~km}$ ), exclusive economic zone (EEZ, 2.02 million $\mathrm{km}^{2}$ ) and various ecosystems of coastal area including estuary, coral reefs, marshes, mangroves, lagoons, rocky and sandy areas [4]. The Andaman and Nicobar Islands, Gulf of Mannar, Gulf of Kachchh and Lakshadweep also fall within the marine waters of EEZ of India.

Conservation of fish is important because of their functional significance and vital role in communities of aquatic ecosystem [5]. In terms of diversity of species, the fish surpass all other groups of animals [6]. The marine fish diversity of India is in ever-increasing danger with depletion of living resources despite the acknowledged notion that it is crucially important for the survival of humanity. Furthermore, fish may be considered as appropriate indicators of aquatic biodiversity, since their rich diversity is reflective of a wide range of environmental conditions [7]. Fish diversity is also reported to be a major element in the health assessments of some estuaries [8]. The lack of a sustainable management regime will further accelerate the rate of resource decline. As a result, 31\% of global fish stocks are classified as overfished and a further $58 \%$ as fully exploited, with no ability to produce greater harvests. The accelerated rate of species extinction and endangerment is a matter of great concern because of species in the wild, being an ingredient of the web of life, has a role to play in the normal working of the ecosystem. The need to preserve biodiversity and sustainably to manage fishery resources is too urgent to be ignored due to depletion of major resources and dwindling catches. The consequences of loss of species from the web of marine life are widespread, affecting the whole ecosystem or micro-ecosystem of which the lost species was a component [9]. Extinction of a species affects other species and can accelerate the extinction of more species through a chain reaction. Most of these concerns have not been translated into a practical reality. Increasing population density, industrial growth and socio-economic development will give rise to a variety of activities, the collective impact of which will multiply the pressures on the coastal zone and its resources.

\section{Indian marine fish diversity}

Every region of the sea is a repository of biodiversity which acts as a home for a wide variety of life. Among various living organisms, fish are most diverse vertebrate occupying various habitats of different types of ecosystem. A healthy habitat requires the variability among species for maintaining the ecosystem's flexibility. The taxonomists have a leading role not only in realizing species diversity but also in protecting its potential by recognizing diversity in the ecosystem and documenting it. The number of fish species reported from fresh and marine waters of India is 3231, which constitutes $9.70 \%$ of fish known from the world [3]. Gopi and Mishra [10] reported 2443 marine fish of India which is 75.6\% of total fish species 
so far reported from India. The estimated number of Indian marine fish species is classified into 230 families, where 12 families are having more than 40 species and other families in order of decreasing number of species are: Gobiidae (190), Pomacentridae (92), Labridae (85), Serranidae (85), Carangidae (66), Blenniidae (65), Apogonidae (63), Chaetodontidae (48), Lutjanidae (45), Sciaenidae (43), Syngnathidae (42) and Myctophidae (41). Nine families of Indian marine fish are monotypic; 7 families have 2 species in 1 or 2 genera; 35 families have 20 or more species and 12 of which have over 40 species. A total of 96 families are represented by only 1 genus each. The order Perciformes is the most species-rich group of Indian marine fish having a total of 1367 species accounting for $56.0 \%$ of the total marine fish species. The other orders such as Scorpaeniformes, Anguilliformes and Tetraodontiformes each contribute $4.30 \%$ of the total Indian marine fish species reported.

A survey of the literature showed that the scientific database of Indian marine fish fauna is scanty and efforts should be made to complete it. However, the Zoological Survey of India has initiated efforts to collect the literature of Indian marine fish and published the state fauna series in order to describe the fish fauna of marine and estuarine waters of Lakshadweep [11], West Bengal [12, 13], Gujarat [14], Puducherry [15], Andhra Pradesh [16], Odisha [17], Tamil Nadu [18], Maharashtra [19], Andaman and Nicobar Islands [20] and Karnataka [21]. Besides, Talwar and Kacker [22] carried out work on 'commercial sea fishes of India' and described a total of 548 species of commercially important Indian marine fish of 89 families.

Knowledge of fish diversity of the particular region is considered to be essential not only for their rational management but also for the conservational strategies for the ichthyo-fauna of that region.

Fish and fisheries today form an important element in the economy of India like many nations. But, some of our own actions such as overfishing of marine waters that upset the integrity of the environment pose serious threats to marine ichthyo-fauna and stocks of fish. The studies are considered to be essential to determine the status of marine fish whether they are threatened or not in order to prevent them from their possible extinction. The efforts on ecosystem restorative measures are needed for restoration of marine ecosystems to check the diminishing population of marine fish.

\section{Causes of fish depletion}

\subsection{Overfishing}

Fish are immensely important to human beings as they have long been a staple food item, but overfishing because of overdependence on fish has led in the dwindling of their many species. Fishing through dynamiting and poisoning, which are the worst forms of reckless exploitation that bring about the mass mortality of fish and inflict considerable collateral damage. Such activities have been considered to be detrimental to lush coral reefs in mega biodiversity regions of the Indo-Pacific [6]. Increasing demand for fish and advancement in technology have drastically enhanced the exploitation of ocean resources and led to serious pressures on marine fish. Lack of management or mismanagement has led the loss of fisheries sustainability. 
Several fish species and stocks have already collapsed, while many others will meet the same fate in the future. When some species are removed, this can lead to loss of other species, shifts in relative abundance and reduced resilience $[23,24]$.

\subsection{Habitat alteration}

Anthropogenic activities are considered to be the major cause of habitat alteration caused by depletion in marine fish diversity. The sea has long been used as an ultimate dumping ground for all kinds of pollutants including solid, liquid, organic and inorganic wastes; in which some are biodegradable, others are not. Marine life is affected by pollutants directly or indirectly which change the whole ecosystems including genetic resources that may cause mass mortalities of fish and other organisms. More devastating are the hidden changes in many species including changes in the genetic composition of marine organisms by directly acting on the DNA to bring about gene mutations (change at a single locus) or chromosomal aberrations (changes of chromosomes at many loci), and by way of environmental modifications which impose selective pressure on genotypes [25]. Discharge of essential nutrients to marine ecosystems can cause eutrophication resulting in algal blooms, oxygen deficits and changes in species composition.

Chemicals pollute the sea, which enter from land, air and rivers. These pollutants may be natural or artificial from industries, agriculture, etc. The chemical pollutants may act on fish directly or by changing the environment indirectly. These chemicals enter into the food chain and affect the organisms in time and space from the source. Those chemicals which are not metabolized may accumulate in the tissues of various organs of the body and affect the organism through biological magnification. Food chains of marine organisms are long, and the members of the upper trophic level of the food chain are affected by the maximum concentration of non-degradable chemical poison, because the carnivores of upper trophic level acquire the chemicals from the eaten prey containing chemicals. So, the top members such as carnivores of food pyramid receive quite significant quantities of the chemical as food chain prolonged. The poison of chemical contamination by biological magnification was found to be in the bodies of oceanic fish like tuna and swordfish. Mustafa and Zofair [26] reported the problem of biological magnification of DDT in carp which led to the proteolysis and interference in pathways of protein biosynthesis.

A number of workers such as Shomura and Godfrey [27], Shomura and Yoshida [28] and Norse [29] reported the accumulation of non-biodegradable solid wastes such as glass, plastic and metal containers in the bed of sea for decades, which change the marine habitats and cause mortality of animal's entanglement and ingestion. Recently, CMFRI [30] reported the occurrence of macroplastics of $5.00 \mathrm{~cm}$ and $3.00 \mathrm{~cm}$ lengths in the gut of Coryphaena hippurus (Linnaeus, 1758) and Euthynnus affinis (Cantor, 1849), respectively, collected from different regions of India Sea.

\subsection{Oil pollution}

Oil spills are considered to be a major cause of marine pollution. Leakage from tankers during transportation of crude oil, a collision of tankers, rigs operation, pipeline leaks and washing of tankers are major sources of oil spills. Oil spills destroy the fish habitats and alter the ecological 
conditions of seawater which led to the mass mortality of fish and other organisms. It is estimated that 252-336 million gallons of oil spilt into the Persian Gulf during Gulf War [31]. Adverse environmental change, especially in spawning habitats, decreases the stock strength of the coastal fish.

Recently, the oil spill was recorded because of the collision of two cargo ships (MT BW Malpe and MT Dawn Kanchipuram) on January 28, 2017 at Kamarajar Port, Ennore. For damage control, it is estimated that 65 tonnes of slick was removed from out of the spillage. The damage of sedentary organisms due to oil pollution near the high toxic level (HTL) at Kasimedu was recorded on a survey conducted between Pazhaverkad and Kovalam coasts of India, but the organisms of the lethal toxic level (LTL) were healthy and unaffected.

\subsection{Fly ash deposition}

The studies on the impact of the effluents from burning coal of Tuticorin Thermal Power Station was carried out for 6 months during July-December, 2017, which indicated that fly ash and hot water discharges are more adversely affected compared to chemical effluents released from thermal power station.

\subsection{Public sewage}

The impact and analysis of untreated municipal or public sewage discharge to the coastal sites of Tuticorin indicated more deterioration condition of the marine water as compared to other sites. Similarly, maximum number $(13 \times 106)$ of total plate count of marine sediment was recorded from the fisheries harbor site at Visakhapatnam than the sites where public sewage is disposed.

\subsection{Climate change}

Burning of fuels, industrialization, urbanization, etc. are major sources of different harmful gases such as $\mathrm{CO}_{2}, \mathrm{CH}_{4}, \mathrm{NO}$ and $\mathrm{CFCs}$ which led to the production of the greenhouse effect. The heating of earth's surface resulting into melting of ice in glaciers and poles are expected to further raise the sea level in the range of $21-71 \mathrm{~cm}$ by the year 2070 . This could mean that many fisheries dependent on upwelling will suffer or cease to exist. The marine fish whose genotypes can withstand the changing environment and new selection pressures will survive as a genetic core for new directions in evolution. At worst, effects could include loss of critical coastal habitats, alterations in oceanic circulation patterns and loss of many existing fisheries. The study of impact of climate change on the vulnerability of Indian marine fish was carried out under the NICRA project, and criteria were developed for exposure, sensitivity and adaptive capacity of Indian species to enable assessment of the vulnerability of fish species.

Criteria were formulated as:

$$
\text { Vulnerability }=(\text { Exposure }+ \text { Sensitivity })-\text { Adaptive capacity }
$$

Vulnerability assessments have been carried out at different centers as per the developed criteria. This also allows for predictive evaluation based on 40-year catch data. For this, 40-year data on fishery biology and environmental parameters of Indian coast were analyzed. 
In India, some institutions at the national or state level are devoted to the study of the propagation of some food fish species, based on their biology and reproductive potential. Hence, government support and active participation of financial institutions may be essential to provide an initial thrust to new ventures. In this framework, the Central Marine Fisheries Research Institute (CMFRI) is the pioneering institution, which has initiated marine aquaculture research and has been developing appropriate marine aquaculture technologies in India [32-38]. Indian marine fisheries data collection is a quite systematic statistically renounced activity in India by CMFRI by the research institutes of the Indian Council of Agricultural Research (ICAR) since 1950s. Monitoring and assessment of the exploited marine fishery resources of India are one of the important mandates of CMFRI. For sustainable fisheries, stock assessment data are considered to be essential and important as a reference for the management of exploited resources. The Indian Institute, CMFRI has been gathering the data by establishing the National Marine Living Resources Data Centre (NMLRDC) regarding the landings of different species of marine fish and their biology. The center has already collected information of the exploited marine fish species and other resources to create a strong data base.

Among the Asian countries, India ranks second in culture and third in capture fisheries production and is one of the leading nations in marine products export. The marine fish landings in India were approximate at 3.63 million tonnes during the year 2016 which is $6.60 \%$ more than the previous year. Rajiv Gandhi Centre for Aquaculture (RGCA) in India has been undertaking natural stock enhancement activities including, breeding of Asian sea bass: cage culture of Asian sea bass; fattening of rock lobsters; breeding and culture of mud crabs; Artemia production; breeding and culture of groupers and culture of Tilapia [39]. But, unfortunately, this phenomenal growth also brought in imbalances in the exploitation across the regions and among the resources. The present situation demands for the development of suitable scientific strategies on the basis of available database of marine resources of region and country wise for the management and exploitation of fishery resources.

\section{Marine fish and their conservation categories}

Various methods have been developed for the conservation assessment of fish. The major classification system used internationally for assessing the status of the threat to each species is that adopted and developed by the World Conservation Union or International Union for the Conservation of Nature and Natural Resources (IUCN). The IUCN [40] Red list is a catalog of taxa that are facing the risk of extinction or the threat in their wild habitats. The fish species restricted to limited geographic area and facing anthropogenic threats because of alteration in their habitats are considered to be more liable for becoming threatened species.

The uses of Red data list are to develop awareness about the importance of threatened biodiversity, identification of endangered species, providing a global index of the decline of biodiversity and defining conservation priorities at the local level and guiding conservation action. Following different categories of threat status were addressed: 
i. Extinct (EX): Extinct taxon is the condition of the species where all the individuals died without suspicion.

ii. Extinct in the wild (EW): Extinct in the wild taxon is the condition of the species where exhaustive surveys failed to record an individual species in habitats and known to survive in captivity or under culture system.

iii. Critically endangered (CR): Critically endangered taxon is species, which is facing great risk of extinction near future in wild.

iv. Endangered (EN): A taxon is endangered whose numbers are so small that the species is at the extreme risk in wild for extinction.

v. Vulnerable (VU): Vulnerable taxon is the species, which is facing a high risk in the wild in some time future for its extinction, but is not endangered or critically endangered.

vi. Near threatened (NT): Near threatened taxon is the species which does not satisfy the criteria of endangered or critically endangered or vulnerable category, but may enter in the category of threatened in near future.

vii. Least concern (LC): Least concern taxon is the abundant and widespread species which does not satisfy the criteria of threatened or vulnerable or endangered and critically endangered categories.

viii. Data deficient (DD): Data deficient taxon is the species whose information on abundance and distribution is considered to be inadequate for its assessment for extinction risk, but its biology may be well known.

ix. Not evaluated (NE): A taxon is Not Evaluated when it has not yet been evaluated against the criteria.

The conservation categorizations of the marine fish of India were assessed by Gopi and Mishra [10] and they put forwarded that 50 species of marine fish are threatened, 6 of them critically endangered, 7 endangered and 37 vulnerable of the 50 threatened fish species, most of them (40 species) are cartilaginous (elasmobranchs-sharks, skates and rays) and the remaining 10 species are teleost fish. In addition, more than 45 species are near threatened.

Marine conservation is a subject that focuses on issues which attempt to save from massive economic disaster. A common resolve for biodiversity protection and sustainable management of fishery resources must exceed geographical boundaries of nations, and there should be the willingness for cost sharing in both in-situ and ex-situ methods of conservation. For each species or population facing genetic risk, the most appropriate conservation methods are in-situ or ex-situ methods.

In-situ conservation strategy is focused on ecosystem preservation from extensive pollution; sedimentation and alienation for possible species management for maintaining a viable fish population size, especially for normal breeding, recruitment and genetic diversity. In-situ conservation of marine organisms is carried out by declaring the appropriate and suitable natural conservation areas such as marine protected areas (MPAs) by designating as National Parks 
or Wild Life Sanctuaries or Biosphere Reserves in order to safeguard the depleted, threatened, rare or endangered species. Presently there are 31 MPAs in India covering a total area of $627.2 \mathrm{~km}^{2}$ [41], out of which 4 National marine parks, 3 marine sanctuaries and 4 biosphere reserves are considered to be very important to protect Indian marine ecosystems with their resources [42] (Table 1).

$E x$-situ conservation strategy is made outside the natural habitat in the form of live collections, gametes or DNA fragments. It can be categorized into two major types including Gene banks are useful for keeping broodstocks of different species and varieties in ponds, tanks and aquaria. Germplasm storage involves cryopreservation, mainly of gametes and embryos. These sources should admit the genetic resources of wild marine fish in addition to their original interest in the management of species. National Bureau of Fish Genetic Resource (NBFGR) is the prime institute of India carrying out fish sperm cryopreservation for longterm gene banking, and has developed the facilities for 27 species so far [43]. Cryopreserved sperm can be effectively utilized in order to overcome the milt-related problems of those fish

\begin{tabular}{|c|c|c|c|c|}
\hline S. no & $\begin{array}{l}\text { Name of marine } \\
\text { protected area }\end{array}$ & Established/created & Total area & Parts of India \\
\hline \multicolumn{5}{|c|}{ Marine national parks } \\
\hline 1. & $\begin{array}{l}\text { Gulf of Kachchh } \\
\text { National Marine park }\end{array}$ & 1980 & $400 \mathrm{~km}^{2}$ & Gujarat \\
\hline 2. & $\begin{array}{l}\text { Gulf of Mannar } \\
\text { National Marine park }\end{array}$ & 1986 & 623 ha & Tamil Nadu \\
\hline 3. & $\begin{array}{l}\text { Mahatma Gandhi } \\
\text { Marine National Park }\end{array}$ & 1983 & $281.50 \mathrm{~km}^{2}$ & $\begin{array}{l}\text { Andaman and Nicobar } \\
\text { Islands }\end{array}$ \\
\hline 4. & $\begin{array}{l}\text { Rani Jhansi Marine } \\
\text { National Park }\end{array}$ & 1996 & $256.14 \mathrm{~km}^{2}$ & Andaman \\
\hline \multicolumn{5}{|c|}{ Marine sanctuaries } \\
\hline 5. & $\begin{array}{l}\text { Bhitarkanika } \\
\text { Gahirmatha Sanctuary }\end{array}$ & 1997 & $1435 \mathrm{~km}^{2}$ & Odisha \\
\hline 6. & $\begin{array}{l}\text { Malvan Marine } \\
\text { Sanctuary }\end{array}$ & 1987 & $29.12 \mathrm{~km}^{2}$ & Maharashtra \\
\hline 7. & $\begin{array}{l}\text { Gulf of Kachchh Marine } \\
\text { Sanctuary }\end{array}$ & 1980 & $295.03 \mathrm{~km}^{2}$ & Gujarat \\
\hline \multicolumn{5}{|c|}{ Biosphere reserves } \\
\hline 8. & Sunderbans & 1989 & $9630 \mathrm{~km}^{2}$ & West Bengal \\
\hline 9. & Gulf of Mannar & 1989 & $10,500 \mathrm{~km}^{2}$ & Tamil Nadu \\
\hline 10. & Great Nicobar & 1989 & $885 \mathrm{~km}^{2}$ & $\begin{array}{l}\text { Andaman and Nicobar } \\
\text { Islands }\end{array}$ \\
\hline 11. & Kachchh & 2008 & $12,454 \mathrm{~km}^{2}$ & Gujarat \\
\hline
\end{tabular}

Table 1. Marine protected areas of India. 
where inadequate milt is produced or because of lack of synchronization in the maturity of two sexes being an issue for induced breeding in several cultivable fish species. An innovative approach for fish conservation was adopted by the NBFGR by declaring a State Fish for each of the states in India in the year 2006 [43]. As a result, 16 states of the country became partners with NBFGR in compliance with this concept for conservation and enhancement of their selected State Fish.

\section{Marine fish management}

The marine fisheries management must be based on population subdivisions into smaller biological units or stocks. Stock-specific fisheries management includes the identification of discrete stocks, their growth, recruitment and mortality, etc. which is carried out on large scale to ensure the sustainability of a population, while maximizing its harvest. Information on morphological, physiological, and behavioral variability, parasite distributions, otolith elemental composition provide insights into a stock structure. Fish stocks are changing because of natural and anthropogenic activities. Therefore, conservation of fish stocks is, needless to say, of principal magnitude for appropriate management purpose through the implementation of different stocking strategies.

\section{Marine stock enhancement}

Marine stock enhancement (MSE) is an integral component of fisheries management involving the release of cultured organisms to enhance or restore the depleting marine fish stock. A large number of countries are investigating the major potential for releasing cultured juveniles to boost up the marine fisheries. In this direction, the First International Symposium on Stock Enhancement and Sea Ranching (ISSESR) was organized in Norway in the year 1997 [44] and the second ISSESR in Japan in 2002 [45]. The Third ISSESR, hosted by NOAA in the United States in September 2006, proposed seven significant themes and also supported the development of restocking, stock enhancement and sea ranching policies for possible sustainable fisheries management. These events were considered to be instrumental in the development of the emerging discipline. Apart from these, other milestones including scientific conferences and reviews have also helped in the advancement of the science regarding releasing a wide range of valuable coastal species [46-57]. Stock enhancement program must be integrated along with a fishery management that involves habitat protection and release of juveniles with appropriate control of fishing effort [58].

\subsection{Restoration of depleted stock}

Restoration of severely depleted stock due to overfishing or any other perilous consequences can be achieved by releasing the cultured juveniles into the natural habitats for its rational exploitation in future. 
It is to reconstruct conservation hatcheries for the implementation of possible conservation strategies to lend a hand to restore endangered or threatened species in wild.

Restocking includes the endeavors to replace the existing, self-recruiting stocks, with stocks having more desirable traits such as higher growth rate, reduced the tendency to stunt, etc. Restocking can thrive more where there is evidence that recruitment limitation cannot be overcome effectively by other fisheries administration tools and limiting factors are implicit. The large-scale restocking is carried out to enhance the depleted stocks of commercially important species to improve catches which may deeply affect the genetic reliability of a population. Ryman et al. [59] have elaborated two kinds of potential genetic concerns associated with this method, that is, introgression, whereby the genetic characteristics of natural populations are compromised by way of loss of adapted genes through interbreeding, displacement or eradication of the entire population due to the introduction of disease(s) and homogenization of a genetically differentiated population as a result of flooding with common exogenous gene pools.

\subsection{Stock enhancement}

The release of cultured juveniles into wild population(s) to augment the natural supply of juveniles and optimize harvests by overcoming recruitment limitation.

The term 'stock enhancement' is often used to describe most forms of stocking with an ultimate goal of enhancement practice to increase stock size of the species which occurred naturally to optimize its harvest or increase catch rates. Both stock enhancement and restocking are likely to be effective for some coastal invertebrate fisheries, because the shallow inshore distribution and sedentary behavior of the species involved can create self-replenishing populations on a relatively small spatial scale [56]. Stock enhancement and restocking are potential measures that could either reduce the time needed to rebuild certain capture fisheries to a more productive level or increase the productivity of some 'healthy' fisheries [57]. An important issue that has immense resource prospect viability via a stock enhancement and sea ranching is ignored. Stock enhancements are separated into two types: (1) The enhancement of existing wild stock for open-access fishery of the fish species which may or may not be self recruiting is called wild fishery, which is carried out in those inland water bodies that are not having property rights for this. In general, the recapture rate of stocked fish is low and repeated enhancement is not always necessary to maintain the fishery. (2) Culture-based fisheries includes stocking of small water bodies undertaken on a regular base and the activity is the only means of satisfying the fishery in the form of stock enhancement practices. In the last 10 years, marine stock enhancement has begun to be treated scientifically [58] and strides are now being on the way in gaining a scientific understanding of the stock-replenishment potential afford by hatchery releases [60]. Restocking and stock enhancement must be positioned within a fishery management scheme to facilitate which integrates releases with appropriate control of fishing effort and habitat protection [57].

\subsection{Sea ranching}

The release of cultured juveniles into unenclosed marine and estuarine environments for harvest at a larger size in 'put, grow and take' operations. 
Sea ranching is also an alternative way to increase productivity from fisheries habitats, wherein animals are released for harvest at a larger size. Sea ranching or artificial recruitment of aquatic organisms is carried out into their natural habitat for stock improvement or enhancing the production and its conservation. The sea ranching technique involves the development of brood stocks, its breeding and larval rearing, nursery rearing and release of seed at suitable sites and monitoring of the released and natural stocks. The history of sea ranching is very old [61] and is said to have been originated in the USA as early as 1870 . Afterwards, many maritime countries such as Japan, Norway and Iceland have launched successful ranching programs for marine stock enhancement. A total of 33 developing countries have reported marine stocking activities involving 59 species [55]. With the development of technologies of controlled breeding, seed production and nursery rearing, the programs of sea ranching of marine prawn, pearl oyster and clams were started in India in the mid-1980s. Ranching is advantageously carried out in bays, lagoons, shallow water bodies and in the protected ecosystems.

The global efforts on marine stock enhancement have begun scientifically in the recent years [58]. In India, natural stock enhancement activities have been undertaking by Rajiv Gandhi Centre for Aquaculture (RGCA), which has already ranched the Asian Sea bass, Lates calcarifer (Bloch, 1790) and the Mud Crab Scylla serrata (Forskal, 1775) at Pazhayaar estuary in Tamil Nadu. The other program of MPEDA-RGCA for sea ranching of 1000 juveniles of the marine finfish, Cobia was the first of its kind in India. The ranching program with tagging of fish before its release was initiated to carry out the research studies to know the type of trophic dependence in the Indian estuarine marine food web [62]. Our knowledge of trophodynamics of marine and estuarine fish is considered to be important and essential in order to sustain the marine stock enhancement.

Stock enhancement of penaeid prawns along the Kerala coast of India was considered to be not successful because of heavy mortality of hatchery-grown post larvae on their release to the sea. Moreover, they were neither acclimatized to the sea water nor acquired skills of predator avoidance. The efforts are intended to revive depleted marine snail species such as Turbinella pyrum (Linnaeus, 1767) (sacred chank), Babylonia spirata (Linnaeus, 1758) (whelk), Volegalea cochlidium_(Linnaeus, 1758) (spindle shells), Chicoreus ramosus (Linnaeus, 1758) (murex) and Chicoreus virgineus (Roding, 1798) along the coast of Tamil Nadu in India. A total of 10,000 juveniles and 0.50 million larvae of the different species of snails were sea ranched in the Gulf of Mannar in the year 2010. Natural stocks of all of the species of snails are exploited for their meat, shells and opercula.

\section{Future prospects}

International and regional cooperation is vital in a global drive for the conservation of marine fish resources, where sea resources contribute substantially to their economy. Since conservation and sustainable management demand limitations on exploitation, a mechanism of financial and technical support which can guarantee continued income through alternate sources 
will be needed. It should be realized that sustainability can be more productive in the long run than over-exploitation which exhausts the resource, leaving people out of work.

Marine diversity is yet to find its deserved place in the teaching and training curricula with respect to the research in the genetic diversity of fish stocks. It is strongly recommended that educational programs should be developed or reoriented to offer a prominent place to the conservation of marine resources. These educational efforts will be deeply facilitated by promoting the development of more interactive multimedia software and the production of standard books on the topic; training and expertise typically need to be built up in the relevant disciplines, such as environmental law, fisheries management and ecological economics. For example, a training course on 'Stock Assessment of Tropical Fishes' was conducted at ICAR-CMFRI. The training Course was jointly organized by the ICAR-CMFRI and Bay of Bengal Programme InterGovernmental Organization (BOBP-IGO), Chennai during November 23-December 6, 2016.

Public awareness about marine biodiversity conservation, particularly its genetic aspect, is too low or non-existent. The fishing community continues to think about breed-release (restocking) as a way of enhancing depleted stocks, and release of alien or genetically modified species as a solution to declining catches without a concern about the genetic implications of doing so. Public knowledge should be promoted by outreach programs in simple language that it may reach and understood by all.

Accountable stock enhancement requires new information on rearing techniques, release strategies, monitoring and evaluation of hatchery-release effects (genetic and ecological) on wild stocks to produce possible disease defense in stocks. For the long-term enhancement strategy and making stocking economically successful harvest, rights are needed to be made.

Proper research involving improvements in seed quality shows unexploited potential to increase survival for future improvement in the efficiency of enhancement. Conditioning fish stocks prior to release will play a major role from the acclimation research on behavioral, physiological, developmental, ecological, environmental and feeding deficits in newly stocked organisms. Both short- and long-term attention is needed in field assessments of the effects of conditioning.

Powerful molecular tools (genetic tags and genetic fingerprinting) must be used which may aid in the genetic management of stocked populations for monitoring wild and hatchery stocks. For example, population genetic structure of Indian anchovy, Stolephorus indicus (Van Hasselt, 1823) studied using mitochondrial DNA markers, microsatellite marker development in Eleutheronema tetradactylum (Shaw, 1804) using next-generation sequencing technology, population genetic structure of Lutjanus argentimaculatus (Forsskal, 1775) using microsatellite markers, molecular taxonomic studies on Protapesgallus_(Gmelin, 1791), Scomber indicus (Abdussamad, Sandhya and Arun, 2016) from the Indian coast.

Advancement needs to be made for selecting release sites, release microhabitat and the magnitude of stocking; density-dependence and carrying capacity are key considerations.

Adaptive management or better-improved methods for evaluating stocking effectiveness, species interactions and environmental influences are key to understand the uncertainties 
about stocking success in a realistic and objective manner in light of the specific objectives of a stocking program. Mitogenomic approach to study environmental adaptation and their response to fluctuations in environmental conditions were studied in Indian oil sardine, Sardinella longiceps (Valenciennes, 1847) using whole mitogenome scans [30]. The evidence was recorded for diversifying selection on ATP6, CO1, CO2, CO3, Cyt b, ND1, ND2, ND4 and ND5 parts of OXPHOS genes, which involved in metabolic divergence for critical adaptation in the structuring of sub-population of Indian oil sardine [30].

Interactions of hatchery and wild stocks should be expected and the effectiveness of increasing production with hatchery releases needs to be tested on a large scale for the enhancement of total production.

For the success in the management of stocked populations effectively, there must be improvements in stocking programs considering institutional arrangements involving all stakeholders, the social and legal framework to integrate stocking plans with harvest regulations, cost-recovery and fisheries management plans to make out the role of government for the possible achievements.

\section{Major challenges}

Significant programmatic funding and also the agency(ies) are absolutely essential for a reliable stocking program for the production and release of an enormous quantity of seed.

Such programs, however, require cooperation from hatchery operators to supply disease-free seed and from fishers to protect the stocked animals until they reach a substantial size in natural waters before harvesting.

Cage culture or aquaculture has made possible the large-scale production of commercial finfish all over the world and considered as the most competent and cost-effective mode of fish cultivation. Marine fish farming in cage has great potential to increase the fish production to compensate the drop in marine fish production. The Indian bays of coastline such as Larson Bay, Andaman and Nicobar, Lakshadweep, Gulf of Mannar, Ratnagiri, Goa, Karwar, Palk Bay, etc. are considered to be ideal sites for cage farming. The Indian institute, CMFRI has already developed and demonstrated the technology for cage farming for marine fish such as cobia, snappers, rabbit fish, sea bass and groupers at selected places along the coastline of India.

India being rich in marine biodiversity, there are opportunities for providing financial benefits to the coastal communities and the profit made should encourage the community to conserve the reckless deteriorating biodiversity. With the growing importance of ecosystem services, there is going to be a lot of importance given to biodiversity conservation and biotechnological interventions. Regarding an association including biodiversity communities, biotechnologists and conservationists will alter the operating environment of the sector from exclusively fishery dependent activities to 'earning from biodiversity conservation'. As the population growth continues, demand for food is going to place even greater pressure on fish 
populations. In India, aquaculture ranks first in providing food and the marine fishery industry is in a phase of rapid growth and thus ranks second after aquaculture. Clearly, we cannot rely, in the future, only on aquaculture or wild-caught seafood of marine fisheries to satisfy the ever-increasing demand. Fishery management agencies worldwide are struggling with the paradox of trying to conserve fish stocks while also meeting an increasing demand for seafood which may fill the gap in supply. Exacerbating this situation leads to stock depletions that they can no longer support fishing. The steadily increasing demand, owing to population growth and human health recommendations to increase seafood in the diet, is placing enormous harvest pressure on wild fish stocks. The alarming consequence of such high demand for seafood is that two-thirds of the world's coastal fisheries are now fully exploited, overexploited or depleted and need to be rebuilt [45].

The widespread human onslaught on aquatic habitats has added a sense of urgency to investigate the possible link between habitat destruction and the breakup of gene pools, reorganization of genetic variability and loss of sustainability in fish populations. Caution is needed in establishing links between the status of fish populations and genetic diversity as determined by molecular tools. Fish have been subjected to so much exploitation pressure and environmental modification that it is necessary to monitor at least the target wild populations for genetic changes. The development of molecular techniques has made it possible to decipher the genetic constitution of a species by chemical tools and has revolutionized our ability to understand the genetic impact of human actions. A genetic variability in marine fish has an adaptive value; hence it is vital for species conservation, long-term survival and the sustainability of fishery in diverse microhabitats. Fish with adaptable genotypes perpetuate and recruit to their population and ensure that a range of genotypes exists probably be competent of thriving in whatsoever environmental conditions prevail. As new technologies are developing, advances are made in stocking technologies too, which may be helpful to replenish recruitment-limited and depleted stocks. Although stocking marine organisms has been practiced for well over a century, there is still lack of knowledge needed to guide the effective use of hatchery releases. Faced with depleted stocks and the expanding gap in seafood supply, there are remaining many essential suspicions about how to use stocking technology fruitfully. Subsequently, there are few good reports of the clearly successful application of hatchery releases to augment marine fisheries. MSE should be targeted at local populations having limited recruitment, high commercial level and over fishing pressures, for example, the demersal fish such as Nemipterus japonicus (Bloch, 1791) and Pampus argenteus (Euphrasen, 1788), as they are found to be less adaptive to climatic variability and do not migrate over large areas, and also have good recapture efficiencies. However, it cannot be expected for practice of highly migratory pelagic fish [63] such as Trichiurus lepturus (Linnaeus, 1758), Harpadon nehereus (Hamilton, 1822), Sardinella longiceps (Valenciennes, 1847) and Rastrelliger kanagurta (Cuvier, 1816) which are continuous spawners and possess the high potential to adapt to climatic changes. Bhathal and Pauly [64] pointed out that there is a scarcity of information on the fish fauna of the Indian coastal zones, and their seasonal occurrences in bays and estuaries. The magnitude of the genetic impacts of stock enhancement programs should depend on the size of the populations and its genetic diversity, stocking intensity, released progenies and gene flow among populations. Monitoring and assessment on stocking impacts in terms of population sizes and genetic 
diversity are also very crucial [65]. The development of breeding technologies is necessary to diminish genetic risks. Bell et al. [57] emphasized on the key elements of the approach which require rigorous research including responsible methods for reducing the cost of producing fit juveniles, optimizing survival of animals released in the wild and minimizing the effects of releases on conspecifics and other species in the ecosystem remain.

It is a matter of immense pleasure that CMFRI is one of the institutions in India and also there is no other research organization better suited for leading India's marine fishing sector to greater heights. The role of CMFRI is to provide scientific sustain and suggestions to the governments and do authentic checks while undertaking the journey. Establishment of state wise National Marine Fisheries Data Centre for the collection of detail information regarding the health of stock, Management Advisories and Marine Stewardship for certification are considered to be important initiatives of CMFRI for proper management of marine fisheries.

Managing the fisheries stock alone will not go ahead to sustainability. Instead, there is a requirement of an urgent call to think upon of the services provided by the entire ecosystem and expand appropriate management interventions. Hence, Ecosystem Approach to Fisheries Management (EAFM) aims at development and management of fisheries, while considering the health of the entire ecosystem. At present, CMFRI present a good example of the integration of Satellite Remote Sensing (SRS) used for establishment of 'e-infrastructure' in the marine fisheries sector. Application of GIS rooted inferences allows better decisions to be made on factors such as closed areas, stock abundance, stock enhancement, marine reserve locations, fishing effort distribution, behavior and fishing mortality rates. The book 'Marine Fisheries and Mariculture in India' is an effort to strengthen the present status of marine fishing and mariculture (marine aquaculture) in India.

This review contributes to a better understanding of what needs to be done and will hopefully serve as a catalyst for further work on the enhancement of marine fisheries. The marine aquaculture scenario of India is vast, as there is great scope for developing farming of shrimps, pearl oysters, mussels, crabs, lobsters, sea bass, sea cucumber and mullets. Although about 1.20 million ha is suitable for land-based saline aquaculture in India, currently only $13.0 \%$ is utilized.

Proper techniques should be used; especially in regard to co-management of stock enhancement and sea ranching is needed. But, it is not easy to evaluate an appropriate stocking level in the present scenario. Stock enhancement and sea ranching are being recast in the new millennium as more useful fishery-management tools than yet before. Marine fisheries scenario reveals that progress in fisheries evaluation methods appropriate to enhancements provides the means for its practical implementation and emphasizes the need for taking an integrated analysis of the role of enhancements within fisheries management systems; through a stakeholder participatory and scientifically learned and accountable planning progression. But, it is convinced that a shortage of funds and lack of expertise and the absence of an effective international mechanism of financial support will hamper conservation in India. An establishment of possible links/network, in addition to the attending technical cooperation and economic support, will be helpful in influencing, motivating and decision-making. It is the quickest possible way of stimulating marine conservation by the development of comprehensive management programs, which aim to defend the environment and safeguard their ecological acquaintances. 
Fish and their diversity are often used as ecological indicators for assessing the health of the habitat, enabling to better understand the significance of their natural heritage and the sustainable livelihood. Consistent views have been expressed by Risser [66], who explained biodiversity's direct relationship with ecosystem processes and with the response of the ecosystem to disturbances. The richer the diversity of life, the greater is the ecosystem's strength and resilience, which allow it to maintain its equilibrium in ecosystem. Realization of the global scale of environmental impacts of economic activities accounts for the unprecedented prominence of the paradigm of sustainable development throughout the world. Preservation of ecosystem integrity and resilience and protection of biodiversity is key to achieve the sustainability of wealth in India. The connectivity of oceans makes marine conservation an issue of global concern. There are, however, great disparities between the industrialized and developing countries in their conservation efforts.

\section{Conclusion}

The marine fish fauna of India stays face to face several threats such as uncontrolled fishing, habitat degradation, sea pollution, etc., because of which presently 50 species are in threatened and 45 near threatened category of IUCN extant. So, marine fisheries need management and conservation measures to maintain sustainable use of marine biodiversity in future. Stock enhancement program must be integrated along with a fishery management that involves habitat protection and release of juveniles with appropriate control of fishing effort.

\section{Acknowledgements}

The author thanks to the Head of the Department of Zoology, University of Lucknow for providing facility for conducting this work and also administrative support. One of the authors thanks the University Grants Commission, New Delhi for the JRF fellowship [Ref No-19/06/2016 (i) EU-V] which is given to undertake advanced research.

\section{Funding}

The work was carried out without any funding.

\section{Conflict of interest}

The authors have declared that no competing interests exist. 


\section{Author details}

Mohammad Serajuddin*, Farah Bano, Madhu Awasthi, Pragya Gupta and Graish Kumar

*Address all correspondence to: lu.fisheries@gmail.com

Fish Biology Research Lab, Department of Zoology, University of Lucknow, Lucknow, UP, India

\section{References}

[1] Bowker GC. Biodiversity data diversity. Social Studies of Science. 2000;30:643-683

[2] Nelson JS. Fishes of the World. Hoboken, New Jersey: John Wiley and Sons, Inc; 2006. p. 601 978-0-471-25031-9

[3] Eschmeyer WN, Fong JD. Species by family/subfamily. 2014. Available from: http:// research.calacademy.org/research/ichthyology/catalog/SpeciesByFamily.asp

[4] Venkataraman K, Wafar M. Coastal and marine biodiversity of India. Indian Journal of Marine Science. 2005;34(1):57-75

[5] Bruton MN. Have fishes had their chips? The dilemma of threatened fishes. Environmental Biology of Fishes. 1995;43:1-27

[6] Mustafa S. Introduction. In: Mustafa S, editor. Genetics in Sustainable Fisheries Management. London: Blackwell Science Publishing; 1999. pp. 3-23

[7] Moyle PB, Leidy RA. Loss of biodiversity in aquatic ecosystems: Evidence from fish faunas. In: Friedler PL, Jain SK, editors. Conservation Biology. Vol. 1992. New York: Chapman and Hall. pp. 128-169

[8] Cooper JAG, Ramm AEL, Harrison TD. The estuarine health index: A new approach to scientific information transfer. Ocean and Coastal Management. 1994;25:103-141

[9] Mustafa S, Awaluddin A, Mokhtar M. Sustainable fisheries management in the west coast of Sabah, Malaysia. Proceedings of the Seminar on Fisheries Management in Malaysia: Alternatives and Directions, Kuala Lumpur, Malaysia; 1995

[10] Gopi KC, Mishra SS. Diversity of marine fish of India fish division, zoological survey of India, Kolkata, West Bengal, India. In: Venkataraman K, Sivaperuman C, editors. Marine Faunal Diversity in India: Taxonomy, Ecology and Conservation. London: Academic Press; 2014. pp. 171-193. DOI: 10.1016/B978-0-12-801948-1.00012-4

[11] Rao GC. Lakshadweep: General features, fauna of Lakshadweep, state fauna series. Kolkata: Zoological Survey of India; 1991;2:5-40 
[12] Talwar PK, Mukherjee P, Saha D, Paul SN, Kar S. Marine and estuarine fishes, fauna of West Bengal, state fauna series. Zoological Survey of India, Kolkata. 1992;3(2):243-342

[13] Kar A, Raut SK, Bhattacharya M, Patra S, Das BK, Patra BC. Marine fishes of West Bengal coast, India: Diversity and conservation preclusion. Regional Studies in Marine Science. 2017. DOI: 10.1016/j.rsma.2017.08.009

[14] Barman RP, Mukherjee P, Kar S. Marine and estuarine fishes. Fauna of Gujarat, state fauna series. Zoological Survey of India, Kolkata. 2008;1:311-411

[15] Mishra SS, Krishnan S. Fish fauna of Pondicherry and Karaikal. Records of the Zoological Survey of India. Occasional Paper. 2003;216:53

[16] Barman RP, Kar S, Mukherjee P. Marine and estuarine fishes. Fauna of Andhra Pradesh, state fauna series. Zoological Survey of India, Kolkata. 2004;5(2):97-311

[17] Barman RP, Mishra SS, Kar S, Mukherjee P, Saren SC. Marine and Estuarine Fish Fauna of Orissa. Records of the Zoological Survey of India. Occasional Paper. Vol. 260; 2007. $186 \mathrm{p}$

[18] Barman RP, Mishra SS, Kar S, Mukherjee P, Saren SC. Marine and estuarine fish. Fauna of Tamil Nadu, state fauna series. Zoological Survey of India, Kolkata. 2011;17(2):293-418

[19] Barman RP, Mishra SS, Kar S, Mukherjee P, Saren SC. Marine and estuarine fish. Fauna of Maharastra, state fauna series. Zoological Survey of India, Kolkata. 2012;20(1):369-480

[20] Rajan PT, Sreeraj CR, Immanuel T. Fishes of Andaman and Nicobar Islands: A checklist. Journal of Andaman Science Association. 2013;17(1):47-87

[21] Barman RP, Mishra SS, Kar S, Saren SC. Marine and estuarine fishes. Fauna of Karnataka, state Fauna series. Zoological Survey of India, Kolkata. 2013;21:277-388

[22] Talwar PK, Kacker RK. Commercial Sea Fishes of India. Hand Book. Vol. 4. Zoological Survey of India. 1984. p. 997

[23] Paine RT. A note on trophic complexity and community stability. American Naturalist. 1980;103:91-93

[24] Pimm SL. Food web design and the effects of species deletion. Oikos. 1980;35:139-149

[25] Mustafa S, Rahman RA. Marine genetic resources and sustainable fisheries management. In: Mustafa S, editor. Genetics in Sustainable Fisheries Management. Britain: Blackwell Science; 1999. pp. 75-98

[26] Hummel H, Patarnello T. Genetics and pollution. In: Beaumont AR, editor. Genetics and Evolution of Aquatic Organisms. London: Chapman and Hall; 1994. pp. 425-434

[27] Mustafa S, Zofair SM. Chemical analysis of internal environmental response of carp Puntius stigma to DDT. International Journal of Environmental Analytical Chemistry. 1985;22:155-159 
[28] Shomura RS, Godfrey ML (eds) Proceedings of the Second International Conference on the Marine Debris; 2-7 April 1989; Honolulu, Hawaii. NOAA Technical Memorandum, NMFS, NOAA-TM-SWFSC-154; 1990

[29] Shomura RS, Yoshida HO (eds) Proceedings of the Workshop on the Fate and Impact of Marine Debris; 27-29 November 1984; Honolulu, Hawaii. NOAA Technical Memorandum, NMFS, NOAA-TM-NMFS-SWFC-64; 1990

[30] Norse EA. Global Marine Biological Diversity: A Strategy for Building Conservation into Decision Making. Washington, DC: Island Press; 1993

[31] CMFRI Annual Report: Central Marine Fisheries Research Institute, Kochi; 2016

[32] Ross DA. Introduction to Oceanography. New York: Harper Collins; 1995

[33] Devaraj M, Pillai VK, Appukuttan KK, Suseelan C, Murty VSR, Kaladharan P, Rao GS, Pillai NGK, Pillai NN, Balan K, Chandrika V, George KC, Sobhana KS. Packages of practices for sustainable, ecofriendly mariculture (land-based saline aquaculture and seafarming). In: Modayi MJ, editor. Aquaculture and the Environment. Indian Branch: Asian Fisheries Society; 1999. pp. 33-69

[34] Pillai VN, Menon NG, editors. Marine Fisheries Resaarch and Mangement. Cochin: Central Marine Fisheries Research Institute; 2000. p. 914

[35] Pillai NGK, Modayil MJ, Ganga U. Marine fishing practices and coastal aquaculture technologies in India. In: Kumar A, Katiha PK, Joshi PK, editors. A Profile of People, Technologies and Policies in Fisheries Sector in India. New Delhi: Proceedings Series 10 National Centre for Agricultural Economics and Policy Research; 2003. pp. 83-121

[36] Modayil MJ. Prospects for Expansion of Mariculture in India-Current Scenario and Future Needs of Indian Fisheries. Visakhapatnam: Decennial Publication of FOFP-2004, Forum of Fisheries Professionals; 2004

[37] Modayil MJ, Sathiadhas R, Gopakumar G. In: Lovatelli A, Phillips MJ, Arthur JR, Yamamoto K, editors. Country experiences India, In: FAO/NACA Regional Workshop on the Future of Mariculture: A Regional Approach for Responsible Development in the Asia-Pacific Region Guangzhou; China: 7-11 March 2006; FAO Fisheries Proceedings No. I. Rome: FAO; 2008. pp. 145-171

[38] Gopakumar G, Nair KRM, Kripa V. Mariculture research in India-status, constraints and prospects. In: Modayil MJ, Pillai NGK, editors. Status and Perspectives in Marine Fisheries Research in India. Cochin: CMFRI; 2007. pp. 316-361

[39] Bhat BV, Vinod PN. Development of seafarming in India-an export perspective. In: Lovatelli A, Phillips MJ, Arthur JR, Yamamoto K, editors. FAO/NACA Regional Workshop on the Future of Mariculture: A Regional Approach for Responsible Development in the Asia-Pacific Region. Guangzhou, China; 7-11 March 2006. FAO Fisheries Proceedings. No. 11. Rome: FAO; 2008. pp. p301-p306 
[40] IUCN. International Union for Conservation of Nature and Natural Resources. 2016. Available from: iucnredlist.org

[41] Singh HS. Marine protected areas in India. Indian Journal of Marine Sciences. 2003;32(3):226-233

[42] Madhavi K, Kumar VV, Reddy AD, Reddy GVS. Conservation of fish faunistic diversity - An Indian perspective. European Journal of Zoological Research. 2012;1(3):80-85

[43] Jena JK, Gopalakrishnan A. Fish genetic resources of India and their management-role and perspective of NBFGR. In: 9th Indian Fisheries Forum Souvenir (9thIFF). 2011. pp. 56-63

[44] Howell BR, Moksness E, Svasand T, editors. Stock Enhancement and Sea Ranching. Oxford: Fishing News Books, Blackwell Publishing; 1999

[45] Leber KM, Kitada S, Blankenship L, Svasand T. (Eds.). Stock Enhancement and Sea Ranching: Developments, Pitfalls and Opportunities. 2nd. Oxford: Blackwell Publishing; $2004.562 \mathrm{p}$

[46] Blankenship HL, Leber KM. A responsible approach to marine stock enhancement. American Fisheries Society Symposium. 1995;15:167-175

[47] Munro JL, Bell JD. Enhancement of marine fisheries resources. Reviews in Fisheries Science. 1997;5:185-222

[48] Travis J, Coleman FC, Grimes CB, Conover D, Bert TM, Tringali M. Critically assessing stock enhancement: An introduction to the mote symposium. Bulletin of Marine Science. 1998;62:305-311

[49] FAO. Marine ranching: Global Perspectives with Emphasis on the Japanese Experience. FAO Fisheries Circular 943. Rome: FAO; 1999

[50] Svasand T, Kristiansen T, Pedersen TN, Salvanes A, Engelsen R, Nævdal G, Nødtvedt M. The enhancement of cod stocks. Fish and Fisheries. 2000;1:173-205

[51] Blaxter JHS. The enhancement of marine fish stocks. Advances in Marine Biology. 2000;38:1-54

[52] Caddy JF, Defeo O. Enhancing or Restoring the Productivity of Natural Populations of Shellfish and Other Marine Invertebrate Resources. FAO Fisheries Technical Paper 448. Rome: FAO; 2003

[53] Molony BW, Lenanton R, Jackson G, Norriss J. Stock enhancement as a fisheries management tool. Reviews in Fish Biology and Fisheries. 2003;13:409-432

[54] Mustafa S. Stock enhancement and sea ranching: Objectives and potential. Reviews in Fish Biology and Fisheries. 2003;13:141-149

[55] Bartley DM, Leber KM, editors. Marine Ranching. FAO Fisheries Technical Paper 493. Rome: FAO; 2004 
[56] Bell JD, Rothlisberg PC, Munro JL, Loneragan NR, Nash WJ, Ward RD, Andrew NR. Restocking and stock enhancement of marine invertebrate fisheries. Advances in Marine Biology. 2005;49. Elsevier: Amsterdam:1-370

[57] Bell JD, Bartley DM, Lorenzen K, Loneragan NR. Restocking and stock enhancement of coastal fisheries: Potential, problems and progress. Fisheries Research. 2006;80:1-8

[58] Bell JD, Leber KM, Blankenship HL, Loneragan N, Masuda R. A new era for restocking, stock enhancement and sea ranching of coastal fisheries resources. Reviews in Fisheries Science. 2008;16:1-8

[59] Rhyman N, Utter F, Laikre L. Protection of intraspecific biodiversity of exploited fishes. Review of Fish Biology and Fisheries. 1995;5:417-446

[60] Grati F, Scarcella G, Bolognini L, Fabi G. Releasing of the European sea bass Dicentrarchuslabrax (Linnaeus) in the Adriatic sea: Large-volume versus intensively cultured juveniles. Journal of Experimental Marine Biology and Ecology. 2011;397:144-152

[61] Moksness E, Stole R. Larvae culture of marine fish for sea ranching purpose: Is it profitable? Aquaculture. 1997;155:341-353

[62] MPEDA Report. 2012. Available from: http://www.mpeda.com/cobia.pdf [Accessed: October 31, 2012]

[63] Kitada S, Kishino H. Lessons learned from Japanese marine finfish stock enhancement programs. Fisheries Research. 2006;80(1):101-112

[64] Bhathal B, Pauly D. 'Fishing down marine food webs' and spatial expansion of coastal fisheries in India, 1950-2000. Fisheries Research. 2008;91:26-34

[65] Kitada S, Shishidou H, Sugaya T, Kitakado T, Hamasaki K, Kishino H. Genetic effects of long-term stock enhancement programs. Aquaculture. 2009;290:69-79

[66] Risser PG. Biodiversity and ecosystem function. Conservation Biology. 1995;9:742-746 
